\title{
Short-term responses of 24 hour N-starved cultures of Phaeodactylum tricornutum to pulsed additions of nitrate at nanomolar levels
}

\author{
P. Raimbault, V. Gentilhomme, G. Slawyk \\ Centre d'Océanologie de Marseille, Faculté des Sciences de Luminy, Case 901, F-13288 Marseille, France
}

\begin{abstract}
A high cell-density chemostat culture and a dilute sample, obtained by adding chemostat culture to a nitrate-free medium, were used to study the uptake of low nitrate concentrations by $24 \mathrm{~h}$ nitrogen-starved populations of the diatom Phaeodactylum tricornutum Bohlin. In contrast with numerous previous studies, nitrate was immediately taken up at a high rate following pulsed nitrate additions of 15 to $100 \mathrm{nM}$. These initial rates exceeded the daily growth rate $\left(0.046 \mathrm{~h}^{-1}\right)$ by a factor of 2.5 over a short time during which the population took up 65 to $80 \%$ of the nitrate added. In high cell-density cultures the transient uptake rate rapidly declined due to the rapid decrease of ambient nitrate, while in dilute cultures high uptake rates were sustained for more than $1 \mathrm{~h}$. Although starvation greatly changed the pattern of the nitrate pulse utilization, this diatom appears to be able to meet its nitrogen requirements in response to a sudden increase of nitrate in the nanomolar range.
\end{abstract}

\section{INTRODUCTION}

New mechanisms have recently been proposed which can sporadically increase the nitrate level in the upper nutrient-depleted layer of the open ocean, suggesting that new production based on nitrate in the sea may be more important than previously thought. First, Klein \& Coste (1984) showed, with a numerical model, the existence of pulsed nitrate supplies due to the erosion of the thermocline induced by intermittent winds. Subsequently this phenomenon was directly described in the field by Eppley \& Renger (1988) who noted an increase of the nitrate concentration up to 100 $\mathrm{nM}$ in the upper layer following moderate wind stress.

For the mechanism of sporadic increase of nitrate levels in oligotrophic areas to be effective, phytoplankton must be capable of rapidly absorbing nitrate in order to utilize these episodic nutrient traces. Although $\mathrm{N}$-limited cultures of phytoplankton have consistently shown enhanced specific nitrate uptake rates (Romeo \& Fisher 1982, Terry 1982, Raimbault 1984, Raimbault \& Mingazzini 1987), even at low nitrate concentration (Raimbault \& Gentilhomme 1990), the capacity for nitrate uptake is thought to decrease after a period of $\mathrm{N}$-depletion (Serra et al. 1978, Collos 1980, Dortch et al. 1982, Parslow et al. 1984). An enhanced uptake rate can be observed only after a several-hour exposure to high nitrate levels (Collos 1980, Raimbault \& Mingazzini 1987). This low initial nitrate uptake by N-starved cells can be due to the loss of an active uptake system (Falkowski 1975) or to the inactivation of the nitrate reductase system (Syrett 1981), although the lack of nitrate reductase activity generally observed may be doubtful because detection of low levels of enzyme activity is difficult (Ingemarsson 1987). Unfortunately, the development of such an induction requirement for nitrate uptake following nitrate starvation is an ecological disadvantage for algal survival in a patchy environment where nitrate supply is thought to be episodic.

However these previous results were obtained in cultures with high initial nitrate concentrations $1>5$ $\mu \mathrm{m})$, i.e. in experimental conditions far from the natural conditions encountered in the sea where pulses of nitrate are thought to occur at nanomolar levels. The responses can be different if the nitrate is supplied at low concentrations. For example, Collos (1980) showed a great decline of uptake rates measured over $1 \mathrm{~h}$ after $24 \mathrm{~h}$ starvation when initial nitrate concentrations were high $(5$ to $20 \mu \mathrm{M})$, but at a concentration lower than 1 $\mu \mathrm{M}$ there was no significant difference from non-deficient cells. In the same way, using small additions $(\ll 100 \mathrm{nM})$ of labelled nitrate $\left({ }^{13} \mathrm{~N}\right)$, Zehr et al. (1989) 
reported a rapid absorption of nitrate and its incorporation into protein in ammonium-limited cells due to the activity of the constitutive nitrate reductase. A better understanding of nitrate uptake by marine phytoplankton is needed to determine how $\mathrm{N}$-depleted phytoplankton respond and adapt to episodic nitrate supplies occurring at nanomolar levels in the field.

In light of the recent experimental results and of the new data concerning the natural fluctuations of nitrate supply, we decided to investigate the capacity of $\mathrm{N}$ starved phytoplankton to take up trace quantities of nitrate. Low nitrate concentrations $(<1 \mu \mathrm{M})$ were added to samples of $24 \mathrm{~h} \mathrm{~N}$-starved cells of the diatom Phaeodactylum tricornutum to simulate an encounter with a nitrate pulse. Estimates of nitrate uptake rates were made by direct measurements of the nitrate concentration in the medium applying the analytical method of Raimbault et al. (1990) to determine nanomolar concentrations of nitrate. The initial transient uptake and the entire pattern of nitrate utilization were described both in high and low cell-density samples to simulate biomass conditions encountered in oligotrophic areas.

\section{MATERIALS AND METHODS}

Axenic stock cultures of the diatom Phaeodactylum tricornutum Bohlin, originally isolated from the Mediterranean Sea off Marseille (France), were kept on f/2 medium (Guillard \& Ryther 1962). The experimental cultures were grown in nitrogen-limited continuous cultures at a dilution rate of $0.04 \mathrm{~h}^{-1}$ as described by Raimbault (1984). The inflow medium was prepared from natural nutrient-poor seawater enriched with $4 \mu \mathrm{M}$ P- $\mathrm{PO}_{4}^{3-}$. Concentrations of trace metals and vitamins were those of $\mathrm{f} / 15$ medium, and the inflow nitrate concentration was $10 \mu \mathrm{M}$. The experimental temperature was $20^{\circ} \mathrm{C}$; the light intensity and regime were $135 \mu \mathrm{E} \mathrm{m}^{-2} \mathrm{~s}^{-1}$ and $12 \mathrm{~h}$ light: $12 \mathrm{~h}$ dark, respectively. The cell-density monitored twice per day with a Neubauer hemacytometer, was $10^{5}$ cells $\mathrm{ml}^{-1}$ during the chemostat run. The outflow was completely nitrate- and nitrite-depleted during the light period and the values of particulate nitrogen (PN) were determined at steady-state from a mass balance where the disappearance of nitrate was assumed to be equal to the increase in PN in the culture (10 $\mu \mathrm{g}$-at. $\left.\mathrm{N}^{-1}\right)$. The level of PN was checked with a CHN analyzer LECO before the uptake experiment and did not significantly differ from the steady-state value estimated from inflow-outflow differences of nitrate concentration. High cell-density (HCD) samples of $\mathrm{N}$-starved cells were obtained from the chemostat culture. Populations of $\mathrm{N}$-starved cells at low density (LCD) were obtained by diluting $50 \mathrm{ml}$ of the chemostat outflow in $950 \mathrm{ml}$ of nitrate-free medium (outflow filtered on a Whatman $G F / F$ filter). To control the validity of the dilution (by a factor 20), the PN was measured after dilution and cell counts were made with a nageotte hemacytometer. The period of starvation was $24 \mathrm{~h}$, during which the population continued growing in batch culture without nitrate supply.

During the uptake experiments, nitrate was added at concentrations ranging from 15 to $1000 \mathrm{nM}$ and then monitored until entire disappearance from the medium, using a Technicon AutoAnalyzer Il according to the high sensitivity procedure developed for the determination of nanomolar concentration of nitrate (Raimbault et al. 1990). Nitrate additions were always performed during the first $2 \mathrm{~h}$ after the onset of the light period. Nitrate uptake rates were calculated by differences in concentration over successive short-time intervals ( 5 to $15 \mathrm{~min}$ ) and estimated in terms of specific rate (per unit of cell nitrogen). To check for possible interference of bacterial contamination in the nitrate uptake during experiments conducted with LCD samples, we monitored the nitrate concentration in the dilution medium over more than $1 \mathrm{~h}$ following an addition of $100 \mathrm{nM}$ nitrate. No nitrate decrease was observed, indicating the absence of contaminant effects under these experimental conditions where filtration of the dilution medium was made under non-axenic conditions.

\section{RESULTS}

After steady-state populations were isolated from the chemostat run, cell division continued during the $24 \mathrm{~h}$ of starvation at a growth rate of $1.10 \mathrm{~d}^{-1}$, leading to a decrease in cell-nitrogen of more than $50 \%$. Fig. 1 shows time variations of nitrate uptake for $\mathrm{HCD}$ samples subjected to nitrate additions ranging from $50 \mathrm{nM}$ to $1 \mu \mathrm{M}$. In all cases, nitrate uptake began after a few minutes $(<5 \mathrm{~min})$. The pattern of utilization of pulses showed different phases which were most evident in the experiment performed with the highest nitrate addition. First, there was an initial phase of high uptake rate which immediately followed a nitrate pulse. The duration of this phase (10 to $30 \mathrm{~min}$ ), as well as magnitude of these initial rates, was clearly dependent on nitrate addition. The initial rate was higher than the growth rate measured during the starvation period $\left(0.046 h^{-1}\right)$ except in the experiment conducted with the lowest nitrate addition (50 nM) where the maximum rate observed during the first 3 min was $0.030 \mathrm{~h}^{-1}$. Such high rates were only temporarily maintained and this transient phase was immediately followed by a drastic decrease in uptake rate down to close to zero, while nitrate was still not depleted. This 


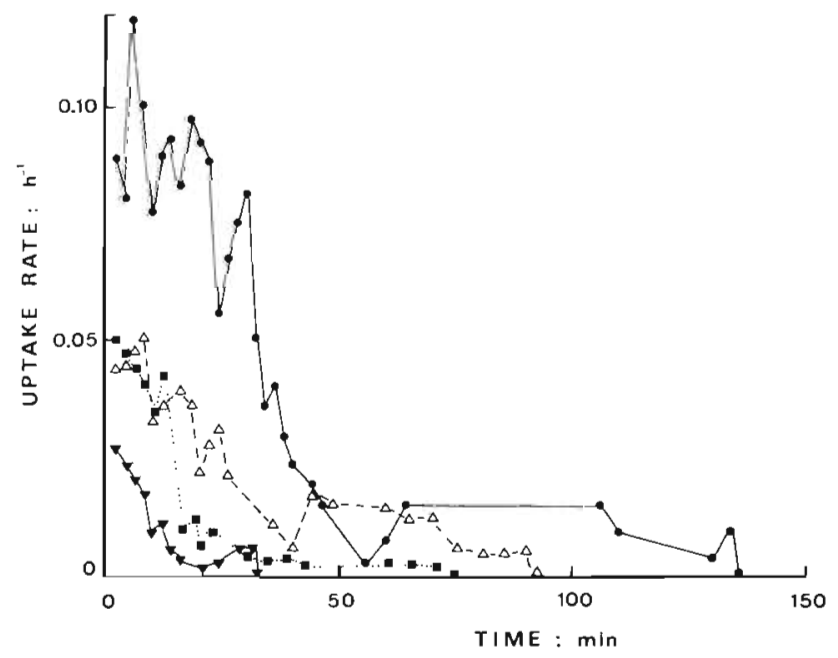

Fig. 1. Phaeodactylum tricornutum. Changes in specific uptake rate $\left(\mathrm{h}^{-1}\right)$ during uptake of nitrate by 24 h nitrogenstarved cells following graded nitrate additions: ( $\bullet 1000 \mathrm{nM}$; (A) $385 \mathrm{nM}$; (1) $133 \mathrm{nM}$; (4) $50 \mathrm{nM}$. Cell-density and particulate nitrogen concentration of these experimental cultures were $2.6 \times 10^{5}$ cells $\mathrm{ml}^{-1}$ and $10 \mu \mathrm{g}$-at. $\mathrm{N}^{-1}$ respectively

reduction of uptake occured when ca 65 to $80 \%$ of the nitrate added was absorbed. Then, uptake slightly increased, up to $0.025 \mathrm{~h}^{-1}$ during the experiments conducted with the highest nitrate additions $(1 \mu \mathrm{M}$ and 385 $\mathrm{nM})$, or remained at a very low level $\left(<0.01 \mathrm{~h}^{-1}\right)$, until nitrate was entirely exhausted from the medium. In all the cases depicted here, the mean uptake rate calculated from the beginning of the experiment until external nitrate became undetectable was lower than the growth rate measured during the starvation period (from 0.010 to $0.032 \mathrm{~h}^{-1}$ ).

When plotted as a function of nitrate concentration in the medium the instantaneous uptake rate, described a sigmoid curve (Fig. 2). In the experiment conducted with $1 \mu \mathrm{M}$ nitrate (Fig. 2a) the phase of maximum uptake rate $\left(0.09 \mathrm{~h}^{-1}\right)$ was well-marked in a 500 to 1000 $\mathrm{nM}$ range of concentration. In the other experiments, where nitrate levels were always lower than $500 \mathrm{nM}$, the plateau was not really reached and the uptake rate seemed to slowly decline with nitrate concentration. Thus, only Expt 'a' showed an apparent saturation of uptake by the substrate. As the drastic decline in uptake rate did not occur at a given nitrate concentration, the last phase, characterized by a very low and more or less constant rate, occurred in the 0 to $10 \mathrm{nM}$ range in Expt ' $d$ ' and in the 0 to $300 \mathrm{nM}$ range in Expt 'a'.

The uptake experiments conducted with the low celldensity (LCD) samples $\left(11 \times 10^{3}\right.$ cells $\mathrm{ml}^{-1} ; \mathrm{PN}=0.5$ $\mu \mathrm{g}$-at. $\mathrm{N}^{-1}$ ) showed some important differences in the pattern of nitrate pulse utilization (Fig. 3). Here, the nitrate additions ranged from 15 to $142 \mathrm{nM}$. Because of the low biomass, the nutrient demand was lower and the time required to exhaust nitrate longer than in the previous experiments. Moreover nitrate was immediately taken up at high rates greatly exceeding the growth rate, except with a nitrate addition of $15 \mathrm{nM}$. This high rate remained more or less constant over a long time (30 to $80 \mathrm{~min}$ ) before slowly declining until nitrate concentration in the medium reached zero. There was no drastic decrease as described above with the HCD samples, but the uptake rate decreased continuously with time, i.e. with fall of nitrate concentration. Mean uptake rates (averaged over the entire period of the pulse consumption) were higher than the growth rate ( 0.05 to $\left.0.07 \mathrm{~h}^{-1}\right)$ except for the experiment performed with $15 \mathrm{nM}$ nitrate $\left(0.022 \mathrm{~h}^{-1}\right)$. The relation observed between the uptake rate and the nitrate concentration was quite different from that observed with
Fig. 2. Phaeodactylum tricornutum. Instantaneous specific uptake rate vs nitrate concentration for the 4 experiments described in Fig. 1 (particulate nitrogen $=10 \mu \mathrm{g}$-at. $\mathrm{N}^{-1}$ ). Initial nitrate concentrations were (a) $1000 \mathrm{nM}$, (b) $385 \mathrm{nM}$, (c) $133 \mathrm{nM}$ and (d) $50 \mathrm{nM}$
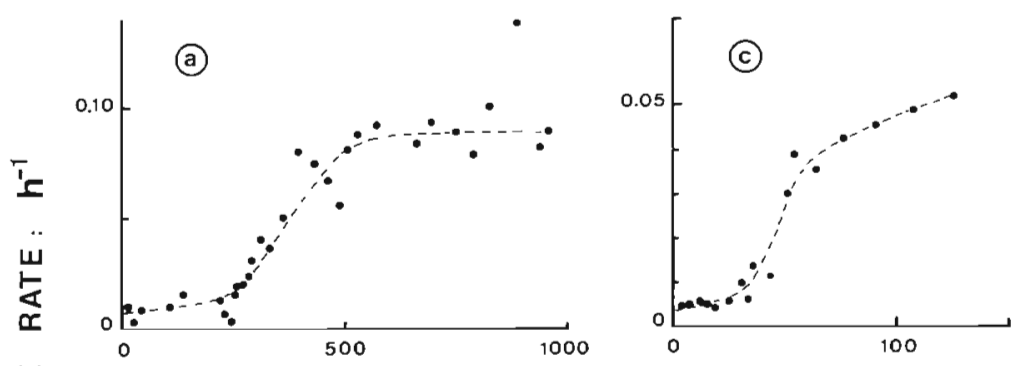

$\frac{\text { 논 }}{5}$
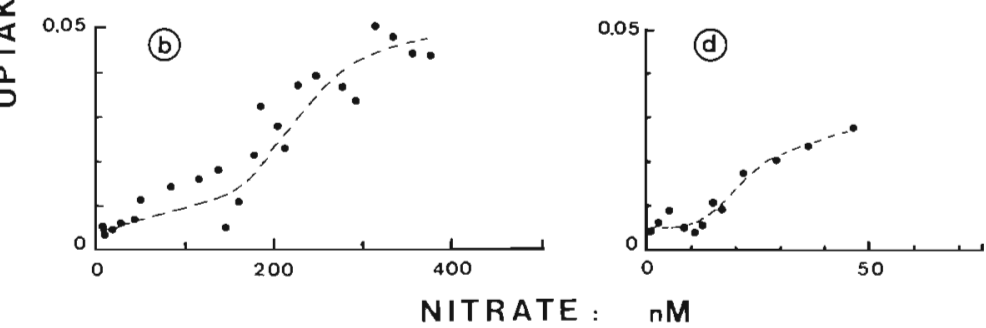


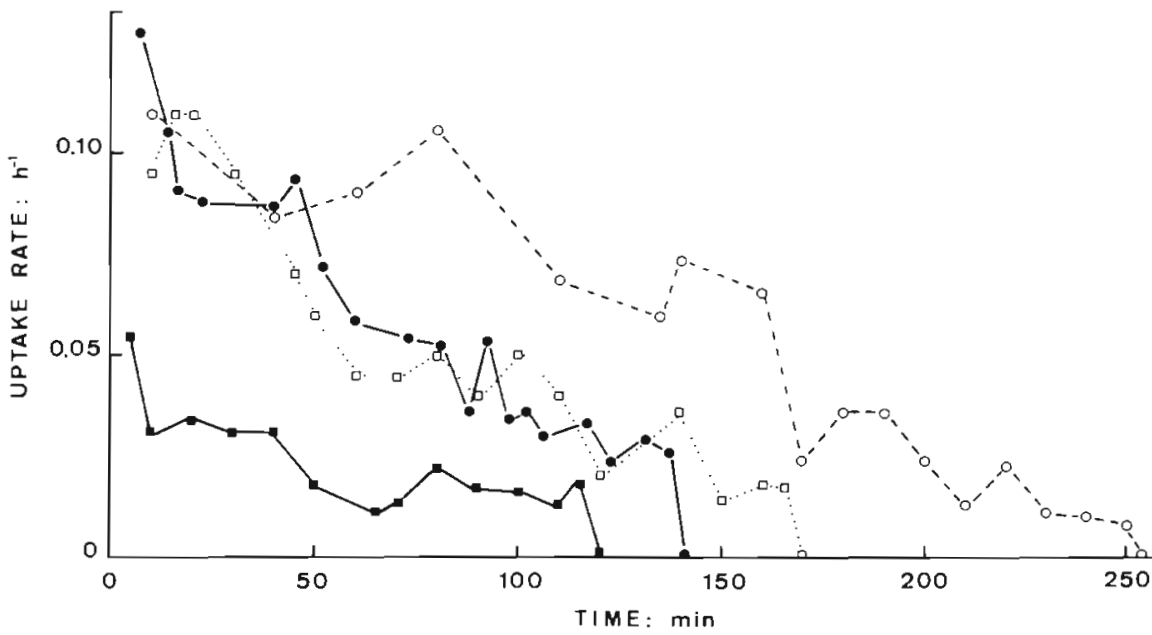

Fig. 3. Phaeodactylum tricornutum. Time variations in specific uptake rate by $24 \mathrm{~h}$ nitrogenstarved cells in samples at low particulate nitrogen $(0.5 \mu \mathrm{g}$-at. $\mathrm{Nl}^{-1}$ ) following graded nitrate additions: (o) $142 \mathrm{nM}$; (c) $75 \mathrm{nM}$; (•) $53 \mathrm{nM}_{\text {; }}(\bullet) 15 \mathrm{nM}$
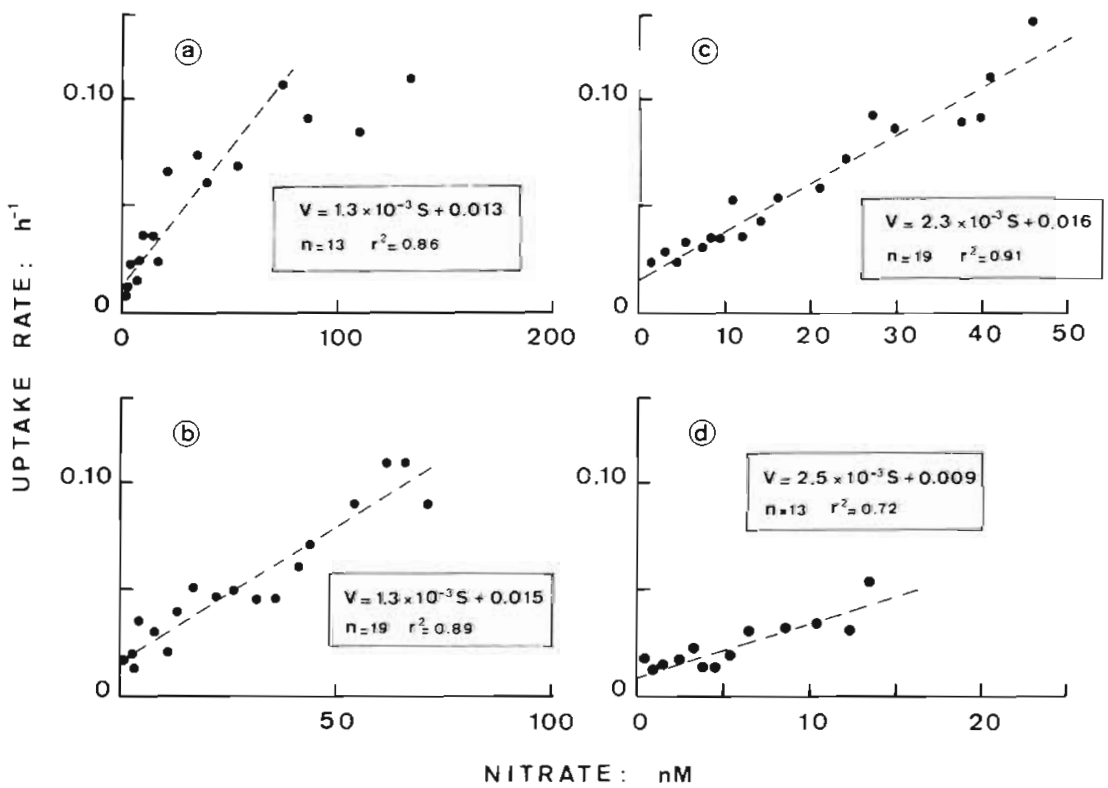

Fig. 4. Phaeodactylum tricornutum. Instantaneous specific uptake rate $\left(\mathrm{h}^{-1}\right)$ vs nitrate concentration (nM) for the 4 experiments described in Fig. 3. Initial nitrate concentrations were (a) $142 \mathrm{nM}$, (b) $75 \mathrm{nM}$, (c) 53 $\mathrm{nM}$ and (d) $15 \mathrm{nM}$

the HCD cultures (Fig. 4). In the LCD experiments, the uptake rate decreased linearly with the decrease of nitrate concentration, except during the initial phase noted during the Expt 'a' where it remained constant $\left(0.10 h^{-1}\right)$ in spite of the important changes noted in the nitrate level. The correlation coefficients calculated from a least-squares regression were highly significant (95\% C.I.) indicating a great dependence of uptake on nitrate concentration.

\section{DISCUSSION}

Although previous studies showed that 24 h nitrogen-starved populations of Phaeodactylum tricornutum required an induction period (30 to $60 \mathrm{~min}$ ) before taking up nitrate at high concentrations (> $5 \mu \mathrm{M}$ ), which have been considered to saturate uptake (Collos
1980, Dortch et al. 1982, Raimbault \& Mingazzini 1987), the present results show that similar N-starved cultures have an extremely high affinity for nitrate at very low concentrations $(<1 \mu \mathrm{M})$. This diatom can rapidly take up $>50 \%$ of small nitrate supplies at an initial elevated rate similar to those found at the beginning of the experiment performed with the $10 \mu \mathrm{M}$ saturating nitrate concentrations (Raimbault \& Mingazzini 1987) and reaching $0.11 \mathrm{~h}^{-1}$, i.e. 2.5 times higher than the growth rate. It should be noted that for equivalent nitrate additions $(<200 \mathrm{nM})$, maximum rates were considerably higher in LCD samples than in HCD samples and were similar to those noted in N-limited cultures (Raimbault \& Gentilhomme 1990). In contrast with the results obtained with high nitrate concentrations, the present uptake kinetics show no subsequent increase in the uptake rate, the maximum rate being reached at the beginning of the experiment. It 
will be noted that very high uptake rates $\left(0.20 \mathrm{~h}^{-1}\right)$ have been observed in saturating experiments following the induction period (Raimbault \& Mingazzini 1987 ) - high rates which remained stable over a long time (more than $1 \mathrm{~h}$ ) because of the saturating ambient nitrate. Here, in non-saturating nitrate perturbation, the uptake rate declined rapidly because of the low nitrate concentration in the medium, and also because of an internal control noticeable on the uptake curve by a truncation occurring at different nitrate concentrations ranging from 30 to 500 nM (Figs. 2 and 4 a). Similar internal control of the uptake rate has been observed in N-limited cells of $P$. tricornutumum for nitrate levels ranging from 100 to 400 nM (Raimbault \& Gentilhomme 1990).

The mean rates of nitrate pulse utilization by HCD samples of both $\mathrm{N}$-starved cells (this work) and $\mathrm{N}$ limited cells (Raimbault \& Gentilhomme 1990) were lower than those found with high nitrate additions (Raimbault \& Mingazzini 1987) and generally lower than the growth rate. But the mean uptake rate observed in LCD samples was higher than the growth rate in both $24 \mathrm{~h} \mathrm{~N}$-starved and N-limited cells of Phaeodactylum tricornutum. Thus, $24 \mathrm{~h}$ N-starved $P$. tricornutum shows the same as $\mathrm{N}$-limited cells to take up rapidly low nitrate supplies at transient rates higher than the growth rate when growing at low cell-density.

The study of phytoplankton responses to low nutrient supply seems to greatly change the concept of growth in oligotrophic environment since it appears that the algae do not have the same physiological responses at low and at saturating nutrient concentration. The physiological mechanisms regulating nitrate uptake are not well known (Collos 1983), but are surely complex according to the sigmoid curves depicted in Fig. 2. However, these curves, obtained with HCD cultures, could not really reflect the natural kinetics of nitrate uptake because the consumption of nitrate was too rapid due to the high biomass. The linear relationship obtained with the dilute culture confirms the direct dependence of uptake rate on the low substrate concentration and could better simulate the pattern of nitrate pulse utilization by a phytoplankton populations growing at low biomass in an oligotrophic area, if the lifetime of small nitrate patches in the sea exceeds some hours. Thus, data on nutrient pulse magnitude and frequency in the field are clearly needed in order to assess primary production on relevant scales. Moreover, the present data point out the need to define carefully the time scales of sampling for studying nutrient kinetics, especially in experiments with high celldensity cultures; they also confirm that great care must be taken in interpreting in vitro uptake rates before drawing conclusions about natural rates.

Several studies have shown that $\mathrm{N}$-starved phyto- plankton is capable of rapid ammonium uptake which can greatly exceed the growth rate (Conway et al. 1976, Glibert \& Goldman 1981). The rates are so high that the cellular nitrogen requirements can be met within a few minutes (McCarthy \& Goldman 1979) and micropatches of ammonium from animal excretion can be used. Since phytoplankton growing in nutrientdepleted areas are less likely to be exposed sporadically to high nitrate concentrations than to high ammonium concentrations, Dortch et al. (1982) hypothesized that phytoplankton do not develop such a rapid mechanism for nitrate. Nevertheless the maintenance of a capability for nitrate uptake after a short period of nitrogen depletion may be an ecological adaptation in response to episodic nitrate pulses caused by the instability of the thermocline (Klein \& Coste 1984, Eppley \& Renger 1988).

Recent information on the distribution of nitrate at the nanomolar level (Eppley \& Renger 1986, Eppley \& Renger 1988, Raimbault et al. 1990) has led to a debate as to whether phytoplankton growth is really limited by the availability of nitrogen in oligotrophic open oceans (Eppley 1980). Kanda et al. (1988) demonstrated that both nitrogen-deficient and nitrogen-sufficient phytoplankton populations occur in oligotrophic areas. Eppley \& Renger (1986) concluded that in coastal areas phytoplankton is continuously exposed to low quantities of nitrate $(<100 \mathrm{nM})$ and is never $\mathrm{N}$-deficient. Even if serious starvation seldom occurs in surface waters, and even if Phaeodactylum tricomutum is not a typical oceanic species, the experiments presented here may be helpful in elucidating the mechanisms whereby nitrogen-deficient diatoms are able to obtain adequate resources under episodic injection of nanomolar quantities of nitrate.

Acknowledgements. This work was supported by the Centre National de la Recherche Scientifique (U. A. 41). The authors are grateful to Mrs M. C. Bonin for help in documentation.

\section{LITERATURE CITED}

Collos, Y. (1980). Transient situations in nitrate assimilation by marine phytoplankton. I. Changes in uptake parameters during nitrogen starvation. Limnol. Oceanogr. 25: $1075-1081$

Collos, $Y$ (1983). Transient situations in nitrate assimilation by marine diatoms. 4. Non linear phenomena and the estimation of the maximum uptake rate. J. Plankton Res. 5: $677-691$

Conway, H. L., Harrison, P. J., Davis, C. O. (1976). Marine diatoms grown in chemostat under silicate or ammonium limitation. 2. Transient response of Skeletonema costatum to a single addition of the limitation nutrient. Mar. Biol. 35: $187-199$

Dortch, Q., Clayton, J. R., Thorensen, S. S., Bressler, S. L., 
Ahmed, S. I. (1982). Response of marine phytoplankton to nitrogen deficiency: ctecreased nitrate uptake vs enhanced ammonium uptake. Mar. Biol. 70: 51-59

Eppley, R. W. (1980). Estimating phytoplankton growth rate in the central oligotrophic oceans. In: Primary productivity in the sea. Brookhaven Symp. Biol. 31, Plenum Press, New York, p. 231-242

Eppley, R. W., Renger, E. H. (1986). Nitrate-based primary production in nutrient-depleted surface waters in California. Océanogr. Trop. 21: 231-240

Eppley, R. W., Renger, E. H. (1988). Nanomolar increase in surface layer nitrate concentration following a small wind event. Deep Sea Res. 35: 1119-1126

Falkowski, P. G. (1975). Nitrate uptake in marine phytoplankton: (nitrate-chloride)-activited triphosphatase from Skeletonema costatum (Bacillariophyceae). J. Phycol. 11 323-326

Glibert, P. M., Goldman, J. C. (1981). Rapid ammonium uptake by marine phytoplankton. Mar. Biol. Lett. 2: 25-31

Guillard, R. R. L., Ryther, R. H. (1962). Studies of marine plankton diatoms. I. Cyclotella nana (Hudstedt) and Detonula confercea (Cleve). Can. J. Microbiol. 8: 229-239

Ingemarsson, B. (1987). Nitrogen utilization in Lemna. I. Relations between net nitrate flux, nitrate reduction, in vitro activity and stability of nitrate reductase. Plant. Physiol. 85: 856-859

Kanda, J., Saino, T., Hattori, A. (1988). Nitrogen nutrition and physiological state of natural populations in surface waters of the western Pacific Ocean. Limnol. Oceanogr. 33: $1580-1585$

Klein, P., Coste, B. (1984). Effects of wind-stress variability on nutrient transport into the mixed layer. Deep Sea Res. 31 $21-37$

McCarthy, J. J., Goldman, J. C. (1979). Nitrogenous nutrition

This article was submitted to the editor of marine phytoplankton in nutrient depleted waters Science 203: 670-672

Parslow, J. S., Harrison, P. J., Thompson, P. A. (1984). Saturated uptake kinetics: transient response of the marine diatom Thalassiosira pseudonana to ammonium, nitrate silicate or phosphate starvation. Mar. Biol. 83: 51-59

Raimbault, P. (1984). Influence of temperature on the transient response in nitrate uptake and reduction by four marine diatoms. J. exp. mar. Biol. Ecol. 84: 37-53

Raimbault, P., Gentilhomme, V (1990). Short- and long-term responses of the marine diatom Phaeodactylum tricornutum to spike additions of nitrate at nanomolar levels. J. exp. mar. Biol. Ecol. (in press)

Raimbault, P., Mingazzini, M. (1987). Diurnal variations of intracellular nitrate storage by marine diatoms: effects of nutritional state. J. exp. mar. Biol. Ecol. 112: 217-232

Raimbault, P., Slawyk, G., Coste, B., Fry, J. (1990). On the feasibility of using an automated colonimetric procedure for the determination of seawater nitrate in the $0-100 \mathrm{nM}$ range: examples from field and culture work. Mar. Biol. 104: $347-351$

Romeo, A. J., Fisher, N. S. (1982). Intraspecific comparisons of nitrate uptake in three marine diatoms. J. Phycol. 18: 220-225

Serra, J. L., Llama, M. J., Cadenas, E. (1978). Nitrate utilization by the diatom Skeletonema costatum. I. Kinetics of nitrate uptake. Plant. Physiol. 62: 987-990

Syrett, P. J. (1981). Nitrogen metabolism of micoalgae. Can Bull. Fish. Aquat. Sci. 210: 182-210

Terry, K. L. (1982). Nitrate and phosphate uptake interactions in a marine prymnesiophyte. J. Phycol. 18: 79-86

Zehr, J. P., Capone, D. G., Falkowski, P. G. (1989). Rapid incorporation of ${ }^{13} \mathrm{NO}_{3}^{-}$by $\mathrm{NH}_{4}^{+}$-limited phytoplankton. Mar. Ecol. Prog. Ser. 51: 237-241

Manuscript first received: September 29, 1989

Revised version accepted: February 26, 1990 